\title{
Investigating The Mathematical Literacy of Primary School Students in Curriculum 2013
}

\author{
Komang Sujendra Diputra \\ Departement of Primary Education \\ Universitas Pendidikan Ganesha \\ Singaraja, Indonesia \\ komangsujendra.diputra@undiksha.ac.id
}

\author{
I Made Suarjana \\ Departement of Primary Education \\ Universitas Pendidikan Ganesha \\ Singaraja, Indonesia \\ imade.suarjana@undiksha.ac.id
}

\author{
I Gusti Ngurah Japa \\ Departement of Primary Education \\ Universitas Pendidikan Ganesha \\ Singaraja, Indonesia \\ igustingurah.japa@undiksha.ac.id
}

\begin{abstract}
This research was based on the results of the PISA (Program for International Student Assessment) publication which showed the mathematics literacy of Indonesian students was still below the average set by PISA. The curriculum 2013 was implemented to follow up on the PISA report which based on identification results found that many competencies in PISA were not adopted in the previous Indonesian Curriculum. Theoretically, learning in Curriculum 2013 should accommodate the contents of mathematical literacy according to the PISA standard. At present, as the implementation of the 2013 Curriculum as a whole in Indonesia, it was necessary to study the effectiveness of the Curriculum 2013 on the development of students' mathematical literacy. Specifically, this study aims to examine the mathematics literacy of elementary school students in curriculum 2013 for thematic learning. The subjects in this study were fifth grade elementary school students in Cluster IX of Buleleng Sub district. Mathematical literacy data were collected using the PISA standardized literacy math test specifically for elementary school students. The results of the study showed that elementary school students were only able to answer level one questions where the concept and how to solve it were clearly visible. The results of the investigation showed that in learning, students were not trained enough to work on problem solving questions and still emphasize on routine and procedural questions.
\end{abstract}

Keywords: mathematics, literacy, curriculum 2013

\section{INTRODUCTION}

One of the 21 st century competencies suggests that students have mastery in the field of mathematics and science in a global perspective. Scientific mastery in the issue of global perspective is very important because Indonesia is in a global community. Therefore, it is necessary to plan strategic steps so that students have readiness and able to compete in the industrial world which is predicted to occur in 2030 [1]. Preparation is not limited to improve the achievement of success of students according to national standards but also how students have the same standard of ability as students in developed countries.

Program for International Student Assessment (PISA) 2015 publishes assessment results for students' mathematical and scientific literacy skills in Indonesia which places Indonesia in 62 places out of 70 countries assessed by PISA. Specifically the results of PISA explained that mathematics literacy of students in Indonesia has a range that is quite far from the standard of mathematical literacy set by PISA.

PISA is one of two international assessments that focus on students' skills and competencies that is obtained from school and can be used in daily life and in various situations, including one of them is mathematical literacy. Assessment conducted by PISA is regularly conducted in three years with the subject being students at the age of 15 years [2].
The definition of mathematical literacy given by PISA is: "Mathematical literacy is an individual's capacity to formulate, employ, and interpret mathematics in contexts. It includes reasoning mathematically and using mathematical concepts, procedures, describing facts and tools, explain and predict phenomena.

It assists individuals to play the role of mathematics in the world and make it well-founded judgments and needed by constructive, engaged and reflective citizens' decisions [1]. Mathematical literacy focuses on the ability to use mathematical understanding in life now and in the future [2]. Thus, mathematical literacy plays an important role for students to prepare students to face their future lives, including the professions they pursue in the future [3].

The government takes seriously the weakness of mathematical literacy based on publications issued by PISA by enacting the 2013 Curriculum. The 2013 curriculum is a follow-up of the PISA report which based on identification results found that many competencies in PISA were not adopted in the previous Indonesian Curriculum [4]. Learning resources must be able to develop mathematical literacy and students must be accustomed to work on PISA model questions in learning practices in school [5].

Based on the 2013 Curriculum guidelines and basic framework, learning in elementary school must refer to thematic approaches starting from the early to high 
grade classes [4]. Although currently in accordance with the new regulations [6], mathematics has returned to be a separate subject previously integrated in thematic learning, in practice mathematics learning remains thematic (context) based. Although mathematics is taught separately in Curriculum 2013, learning must be based on a global context, connected to the dimensions of other subjects, and able to develop the skills needed in the $21 \mathrm{st}$ Century.

Thematic concept is actually not new in the world of education especially in mathematics. Thematic mathematics is organizing curriculum, concepts, strategies, and skills through a central theme (real-life) to provide meaningfulness in the learning process [7]. The purpose of this thematic mathematics is that students are able to solve real problems referring to a central theme designed, using basic mathematical abilities [8].

Early literature studies showed that there were mutually supportive relationships between the 2013 Curriculum conceptions, thematic mathematics, and mathematical literacy. This means that learning in the 2013 curriculum should effectively develop mathematical literacy through teaching materials and mathematical problems (problems) given in learning. The initial identification found that some elementary school teachers in Buleleng Regency had a lack of understanding of mathematical literacy and its forms of problem.

This was reasonable considering the mathematical literacy instrument issued by PISA was used for 15-yearold students. Publications related to the dimensions and level of mathematical literacy issued by PISA were considered complicated by the teacher, so that the questions presented in the study only come from books issued by the government including the giving of questions in them.

Based on the explanation of the relationship between the 2013 Curriculum concept towards the development of mathematical literacy, it was necessary to conduct research to identify and explore more deeply the dimensions of mathematical literacy abilities of elementary school students using valid and specialized mathematics literacy assessment tools for elementary school age. This also measures the potential impact of the 2013 Curriculum on the development of students mathematical literacy.

\section{METHODOLOGY}

This research was a continuation of the previous research, namely "Thematic Based Instrument Development in Accordance with PISA Standards to Measure Mathematical Literacy of Primary School Students in the 2013 curriculum in Buleleng Regency" [9]. In this study, a mathematical literacy assessment tool specifically for elementary school students was based on themes in the 2013 Curriculum in the context of local issues in Buleleng Regency.

The research that would be conducted this year aims to investigate mathematical literacy according to the level of ability set by PISA. Therefore, this type of research was a type of descriptive research. Subjects in this study were grade 5th of elementary school students of cluster IX Buleleng Sub district which numbered of 192 students and were distributed in four schools namely SDN 1 Banjar Jawa, SDN 3 Banjar Jawa, SDN 5 Banjar Jawa, and SDN 1 Astina.

The data was collected in this study consisted of mathematical literacy data in 2013 Curriculum Thematic Learning and in-depth explanations related to students' difficulties in solving PISA standard questions developed by researchers. Mathematical literacy tests used PISA standardized student mathematics literacy tests specifically for elementary school students [9]. The mathematics literacy test was tested on 79 Undiksha Laboratory elementary school students and it had been proven valid with a degree of reliability of 0.72 (high). Examples of problem items used were as follows.

$\begin{array}{ll}\text { Title } & \text { : Teacher } \\ \text { Content } & \text { : Quantity } \\ \text { Context } & \text { : Job } \\ \text { Process } & \text { : Apply facts, concepts, principles and } \\ & \text { procedures } \\ \text { Level } & : 1\end{array}$

Pak Gede works as a teacher. He taught at SD Tunas Karya. Pak Gede has 4 male friends who also work as teachers in the same school. While female teachers at the school are twice as many male teachers. How many teachers teach at SD Tunas Karya?.
A. 9
B. 12
C. 15
D. 18 .

The question items developed were expanded multiple choice types, so that the scoring guidelines used were in Table 1 below.

\section{TABLE 1}

Multiple choice type extended the response of assessment rubric

\begin{tabular}{|l|l|}
\hline Score & Criteria \\
\hline 0 & No answer \\
\hline 1 & Answering, but wrong or misconception \\
\hline 2 & $\begin{array}{l}\text { Answering right, but showing no reason, or showing wrong } \\
\text { reasons or misconceptions }\end{array}$ \\
\hline 3 & Answer correctly and show the right reasons \\
\hline 4 & $\begin{array}{l}\text { Answering correctly, showing the correct reasons } \\
\text { accompanied by evidence: principles, formulas, or } \\
\text { calculations }\end{array}$ \\
\hline
\end{tabular}

The interview sheet was used to obtain in-depth information about the students' difficulties made in math literacy tests. Interviews were conducted on two students who were the subjects of the study and randomly selected. The interview sheet was compiled by the researcher and validated by the experts at Ganesha University of Education. The data in this study were analyzed using quantitative and qualitative descriptive analysis.

\section{FINDINGS}

The results of the recapitulation of students' answers to the mathematics literacy test were summarized in Table 2 below.

Based on Table 2, the percentage of students who managed to answer correctly was accompanied by systematic and logical completion steps, namely: for level 1 questions as much as $67.71 \%$, level 2 questions as much as $3.13 \%$, level 3 questions as much as $0.52 \%$, and $0 \%$ for level 4, 5 and 6 questions 
TABLE 2

Recapitulation of students' math literacy scores

\begin{tabular}{|l|l|l|l|l|l|}
\hline \multirow{2}{*}{$\begin{array}{c}\text { Question } \\
\text { Level }\end{array}$} & \multicolumn{5}{|c|}{ Frequency of Scoring (\%) } \\
\cline { 2 - 6 } & $\mathbf{4}$ & $\mathbf{3}$ & $\mathbf{2}$ & $\mathbf{1}$ & \multicolumn{1}{|c|}{$\mathbf{0}$} \\
\hline Level 1 & 67.71 & 17.19 & 0.00 & 0.00 & 15.10 \\
\hline Level 2 & 3.13 & 5.21 & 23.44 & 63.54 & 4.69 \\
\hline Level 3 & 0.52 & 0.52 & 30.73 & 56.25 & 11.98 \\
\hline Level 4 & 0.00 & 0.52 & 18.23 & 59.38 & 21.88 \\
\hline Level 5 & 0.00 & 0.00 & 15.10 & 60.42 & 24.48 \\
\hline Level 6 & 0.00 & 0.00 & 15.10 & 51.56 & 33.33 \\
\hline
\end{tabular}

The results of in-depth interviews with classroom teachers were found that teachers lacked a clear understanding of the concepts and characteristics of mathematical literacy. In learning, teachers tend to provide procedural questions in textbooks and sometimes provided problem solving questions but were simple. The teacher also believed that making the questions according to the PISA mathematical literacy criteria was still difficult. The results of interviews with students found that students who succeeded in answering questions level 2 and 3 because they were more taught in tutoring outside of school.

\section{DISCUSSION}

Generally, students found difficulties to; (1) formulate mathematical situations and identify mathematical structures (including order, relationships, and patterns) in the problem, (2) evaluate and provide arguments against mathematical solutions in the context of real-world problems [10]. Questions such as PISA questions could encourage the development of student's creativity [11], therefore learning resources in the 2013 Curriculum especially SD textbooks needed to be modified and refined by integrating advanced problem solving questions according to the dimensions of PISA mathematical literacy.

\section{CONCLUSION}

The results showed that students only managed to answer questions about level 1 math literacy, namely questions with clear questions and all relevant information available with clear questions. They can identify information and complete routine procedures according to explicit instructions. While for advanced questions, students tend to have difficulty understanding the questions and concepts used to complete.

\section{REFERENCES}

[1] OECD. PISA 2015 Assessment and Analytical Framework: Science, Reading, Mathematic and Financial Literacy. Paris: OECD Publishing. (2016).

[2] Stacey, K. The PISA view of mathematical literacy in Indonesia. Vol 2, No. 2. Journal on Mathematics Education. (2014)

[3] Gatabi, A. R., Stacey, K., \& Gooya, Z.. Investigating grade nine textbook problems for characteristics related to mathematical literacy. Vol 24, No. 4. Mathematics Education Research Journal. (2012)

[4] Peraturan Menteri Pendidikan dan Kebudayaan Nomor 67. Jakarta: Kemendikbud. (2013)

[5] Zulkardi. Developing a learning environment on realistic mathematics education for Indonesian student teachers. Published Dissertation. Enschede: University of Twente. (2002)

[6] Peraturan Menteri Pendidikan dan Kebudayaan Nomor 24. Jakarta: Kemendikbud. (2016)

[7] Handal, B., \& Bobis, J. Instructional styles in the teaching of mathematics thematically. Vol 10, N0. 2, pp 181-187. International Journal for Mathematics Teaching and Learning. (2003)

[8] Griffiths, M. Thematic mathematics: the combinatorics of prime factorizations. Vol. 29, No. 1, pp $25-40$. Teaching mathematics and its applications. (2009)

[9] Diputra, K.S. \& Sukmana, A.Y.I. Pengembangan Instrumen Berbasis Tematik Sesuai Standar PISA Untuk Mengukur Literasi Matematika Siswa Sekolah Dasar Pada kurikulum 2013 di Kabupaten Buleleng. Laporan Penelitian. (2018)

[10]Edo, S. I., Ilma, R., \& Hartono, Y. Investigating secondary school students' difficulties in modeling problems PISAmodel level 5 and 6. Vol 4, No. 1. Journal on Mathematics Education. (2014).

[11]Novita, R., \& Putra, M. Using Task Like PISA's Problem to Support Student's Creativity in Mathematics. Vol 7, No. 1. Journal on Mathematics Education. (2016). 